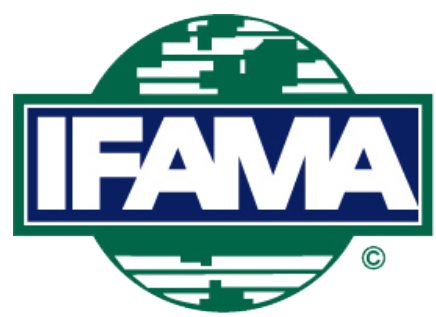

International Food and Agribusiness Management Review

Volume 23, Issue 4, 2020; DOI: 10.22434/IFAMR2019.0179

Received: 5 November 2019 / Accepted: 30 April 2020

\title{
Cultivation of faba beans for regional protein supply: a case study on the association 'Rheinische Ackerbohne e.V.' CASE STUDY
}

\author{
Ina Stute ${ }^{\circledR a}$, Bruno Kezeya-Sepngang ${ }^{a}$, Verena Haberlah-Korr ${ }^{b}$ and Marcus Mergenthaler ${ }^{b}$ \\ ${ }^{a}$ Research associate, ${ }^{b}$ Full Professor, Fachhochschule Südwestfalen, Lübecker Ring 2, 59494 Soest, Germany
}

\begin{abstract}
Faba beans have been an important component in human and animal nutrition in many parts of the world for long periods of time. Soybean imports from overseas have been displacing domestic protein crops in Europe since the 1950s. Although the cultivation of faba beans entails different eco-system services, they are rarely cultivated due to their low market performance. The societal benefits and provisions of eco-system services of cultivating faba beans are well recognized by the non-profit association 'Rheinische Ackerbohne e.V.' (association for faba bean cultivation in the Rhineland). The board and the members of the association are mainly farmers but also agricultural trade companies. The association was founded to strengthen the cultivation of faba beans in the Rhineland, a region in Western Germany. For this purpose, promoting products made from local faba beans, and raising the awareness about faba beans, which may protect bees and the environment, shall help to establish market structures and a regional value chain.
\end{abstract}

Keywords: food systems, faba beans, market structures, promotion JEL code: Q00, Q01, Q12, Q13, Q15, Q18, Q50, R10, R11, R14

\footnotetext{
(1)Corresponding author: stute.ina@fh-swf.de
} 


\section{Introduction and background}

\subsection{Current state of faba bean cultivation in Germany}

Currently, the cultivation of grain legumes in Germany is negligible. They are cultivated on less than 5\% of the arable land as only parts of the private and societal benefits of the crop generate a market value. The cultivation of faba beans results benefits to famers within the system-boundaries of the farm, however, the benefits go beyond farm-boundaries and concern the whole ecosystem.

\subsection{Historical development of faba beans}

Faba beans have been cultivated in Europe for 5,000 to 6,000 years. Their origin could not be clarified yet, but it is assumed that it is located in the region around the Mediterranean Sea (Muehlbauer and Tullu, 1997). Until the $17^{\text {th }}$ century, faba beans were one of the basic foodstuffs in Europe. People appreciated them especially in the winter because of their outstanding storage properties and high level of protein. During the $17^{\text {th }}$ century, the displacement of faba beans in human nutrition began due to the import of new legume varieties and potatoes from overseas. Since that time, faba beans have been increasingly used as a protein supplier in mixed feed rations for animal nutrition (Plantura).

In the 1950 s, soybean imports from overseas began to oust the faba bean as a protein supplier in animal nutrition (Bockholt, 2018: 16; De Visser et al., 2014). In the meantime, soy was established on the market and the cultivation of faba beans was reduced (Lehmkuhl, 2018: 5; Zander et al., 2016). Faba beans became a niche product in Europe and Germany. In 2010, faba beans were cultivated on less than $0.1 \%$ of the agricultural land in Germany (Destatis, 2018).

\subsection{Possible uses of faba beans}

Faba beans are well suited in human nutrition, because they are gluten-free and low in fat, have a high protein content of about 26\% and are high in fibers (Bockholt, 2018: 16; Geil and Anderson, 1994). Until the 1950s, these properties were highly valued and the faba bean was a popular food. In contrast to the Near East, the Mediterranean Region and South America, faba beans play currently only a minor role in human nutrition in Europe, (Multari, 2015). Faba beans are processed into traditional dishes, such as foul, falafel and humus (Bockholt, 2018: 16; Hassan Wassef, 2004).

Faba beans are also suitable in animal feed because they have an increased crude protein and starch content. Due to the secondary plant metabolites of faba beans, such as tannin and vicin, they are limited in their use in pig and poultry feeding. Newer varieties have a lower content of tannin and vicin, which can increase the proportion of faba beans within the feed ration. The use of the protein plant in rations of cattle feeding is possible without restriction; also because the tannin is beneficial for the degradability of nutrients in the rumen (Abel et al., 2020). The use of faba beans can replace imported, genetically modified soy so that regional, GMO-free food is produced (Bockholt, 2018: 16). There seems to be untapped demand for animal products produced with domestic protein feeds (Profeta and Hamm, 2019).

While the awareness and the concerns of North-Americans about genetically engineered food is very low, Europeans have more concerns (Lucht, 2015). The European Commission conducts public opinion polls. These are published under the name Eurobarometer. In 2010, Eurobarometer describes that $61 \%$ of the European population agreed that GMO food should not be supported (European Commission, 2010). 


\subsection{Ecosystem benefits of faba beans}

Ecosystem services are defined as 'direct and indirect contributions of ecosystems to human well-being' (BISE, 2020). The cultivation of faba beans provides various ecosystem services: on the one hand at the farm level and on the other hand beyond the farm boundaries.

Faba beans as leguminous plants are able to provide nitrogen by symbiotic $\mathrm{N}$-fixation in the root nodules. This saves fertilization for the legume and the subsequent crop requires less fertilizer. This significantly reduces energy and fertilizer costs. A further fertilizer related pre-crop effect is the potential to increase availability of soil phosphorus to the subsequent crops (Köpke and Nemecek, 2010).

The deep-rooted taproots of the faba beans improve the soil structure. Due to the improved soil structure and good supply of nitrogen to the soil, yields of the following crops increase in the rotation. The further crop rotation and the introduction of plants sown in spring into the rotation also reduce weed as well as other pest pressure and thus pesticide amounts and costs are reduced (KTBL, 2014: 5; Wahbi et al., 2016). Due to the improved soil structure, the subsequent crop can be cultivated in direct sowing which reduces effort and costs for soil tillage.

The cultivation of faba beans also provides benefits for the ecosystem beyond the farm boundaries (Köpke and Nemecek, 2010). Faba beans increase the biodiversity in crop rotations. Thereby they strengthen the associated diversity of wild flora, wild fauna and soil microbes. Faba beans bloom from May to June and provide a habitat for bees, bumblebees or butterflies (Bockholt, 2018). In life cycle assessments, faba beans have been sown to reduce energy consumption and greenhouse gas emissions compared to agricultural systems based on mineral nitrogen fertilization. Crop rotations with faba beans show reductions in ozone formation, acidification and ecotoxicity compared to intensive cereal-rich crop rotations (Köpke and Nemecek, 2010). Furthermore, the cultivation of faba beans can provide economic ecosystem services. The innovation can create new value chains that link stakeholders and offer them new economic perspectives.

\subsection{Current situation of faba bean marketing}

Despite the advantages in human nutrition and animal feed, as well as the positive ecosystem benefits of grain legumes within and beyond farm boundaries, faba beans are grown on less than $0.5 \%$ of the cropland in Germany in 2018 (Destatis, 2018).

Only small quantities of faba beans are sold to feed manufacturers. The processing of small amounts would lead to small parts of the total feed production containing faba beans. Moreover, a continuous delivery throughout the year is not possible. Furthermore, additional storage capacity would have to be established. For these reasons, the processing of faba beans in animal feed production is currently associated with a significant additional expense for feed manufacturers. In food processing, faba beans are hardly used. As a result, the marketing structures for faba beans in Germany are missing.

Therefore, the market for grain legumes in Germany can currently be described as a fragmented and opaque niche market. So far, there are only a few known price information systems (Kezeya-Sepngang et al., 2018; MPB, 2018). In the medium term, farmers who produce faba beans can only react with an adjustment of the supply quantity and have to orientate themselves towards offered prices in short term. If individual farms only have a small share of production, this results in a weak bargaining position with the effect of a small impact on prices. Overall, the negotiating position in the legume trade for farmers is also weak, because there are few price indicators in consideration of the value creation possibilities and the existing price information systems are based on interested reports of trading companies (Kezeya-Sepngang et al., 2018). 
From the farmers' point of view, feed manufacturers pay too little for the faba beans in comparison to the benefit. From the farmers' perspective, the price of faba beans should rather be based on the prices of genetically unchanged soy than on GM-soy.

\subsection{Promotion of the cultivation of faba beans}

The European Union, the German Federal Government and the governments of several federal states also appreciate the described positive benefits of faba beans. There have been made attempts at different levels to strengthen the cultivation of legumes within the protein crop strategy with active governmental support (BMEL, 2016).

The protein crop strategy has been initiated in 2012 by the Federal Government with the aim of expanding legume cultivation areas, increasing the supply and demand for domestic legumes, and thus improving the ecosystem benefits and resource conservation. Regional value chains have to be strengthened and the protein supply with genetically unmodified protein provider has to be improved. For these reasons, leguminous research has been financially supported and furthermore demonstration networks have been established. The demonstration networks already exist for the crops of peas and beans, lupines and soybeans with the aim of supporting the cultivation and processing of the respective crops, bringing together supply and demand, strengthening extension services and knowledge transfer.

In addition, the German Government supports the measures, which are based on two pillars, of the EU Common Agricultural Policy (BMEL, 2016). The European Union allocates funds as part of the common agricultural policy.

The first pillar covers direct payments to the farmers. These are granted per hectare of arable land. Farmers receive $30 \%$ of these direct payments - the so-called greening premium - only through the provisioning of additional environmental services. These environmental services could be for example: the preservation of permanent grassland, the increased crop diversification and the provision of so-called 'ecological focus areas' on arable land. Leguminous crops can be taken into account as part of the provision of ecological focus areas (EU, 2019).

The second pillar covers the support programs of the individual EU member states for sustainable and environmentally sound management and rural development. In Germany with its Federal Constitution, the second pillar EU programs are designed and implemented at the level of the federal states. The EU and the governments of the federal states jointly fund these programs co-financed by the German Federal Government. Nine out of sixteen federal states support the cultivation of legumes in second pillar programs (Figure 1). In the federal state North Rhine-Westphalia (NRW), for example, there is the agri-environmental measure 'cultivation of diverse crops in agriculture'.

The NRW Chamber of Agriculture describes the funding conditions for this agri-environmental measure funded since 2016 as follows (LWK-NRW, 2018):

The condition for granting a financial support to farmers is that they guarantee:

- to cultivate at least five different main crops every year on the arable land; the share of this main crop must be at least $10 \%$ and maximum of $30 \%$ of the arable land;

- to limit the extent of areas with roughage mixtures containing legumes, to max. $40 \%$ of arable land;

- not to exceed a cereal share of $66 \%$ of the arable land;

- to grow vegetables and other garden plants to a maximum of $30 \%$ of arable land;

- to cultivate legumes or a mixture containing legumes on at least $10 \%$ of the arable land.

The funding period comprises five years. By participating in this support program, the direct payment to the farmers increases by $€ 125$ per hectare of eligible agricultural land (LWK-NRW, 2018). In this way, interested farmers are given a financial incentive to grow grain legumes. 


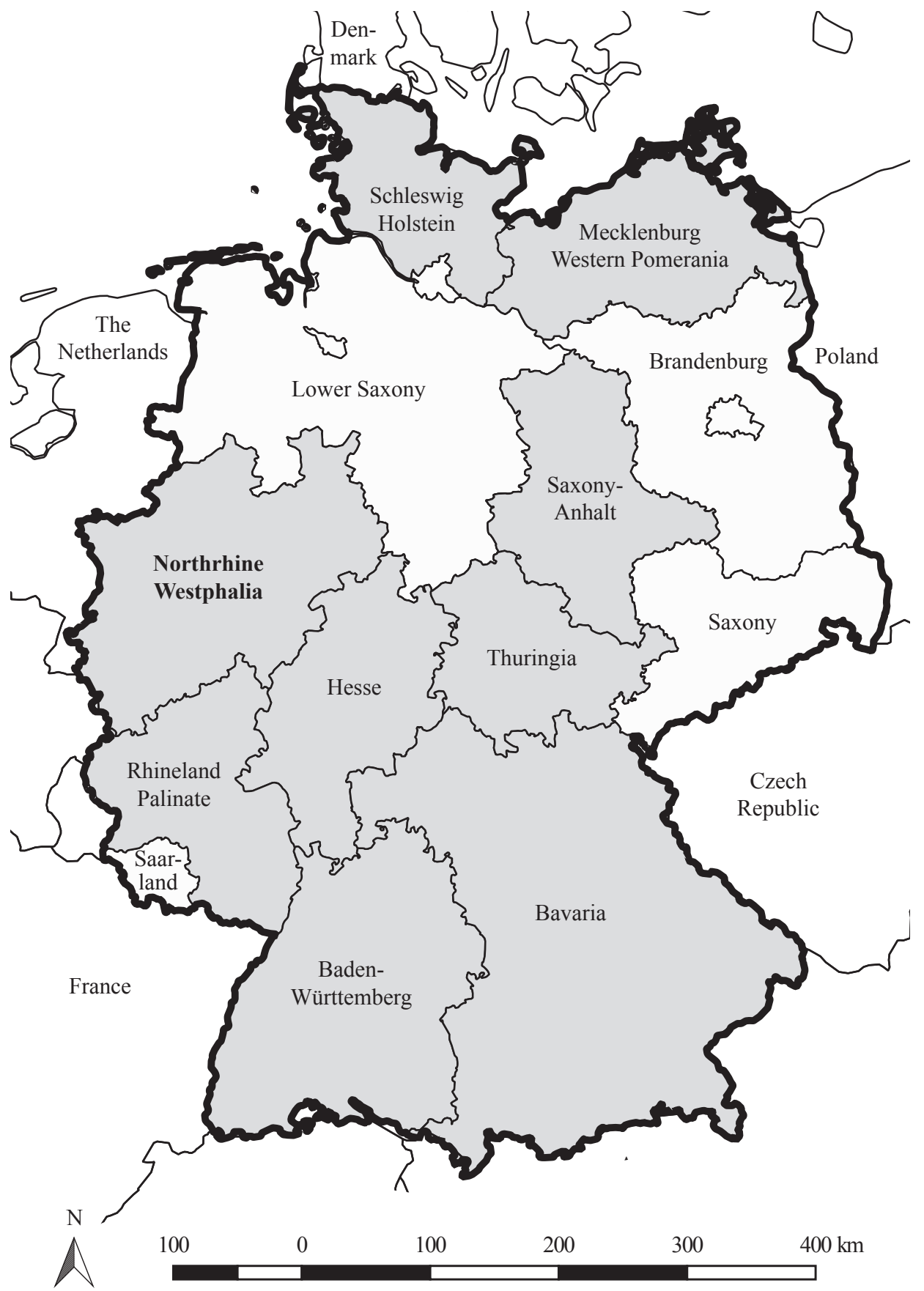

Figure 1. The Federal Republic of Germany. Federal states who offer programs that promote the cultivation of legumes are colored grey (BLE, 2017).

\subsection{Development of faba beans since 2010}

The measures to promote legume cultivation in Germany have been successful in an ex-post perspective so far. In Figure 2, at the latest from 2014, a clear increase in acreage is noticeable. In 2011, before a state support for the cultivation of protein crops began, 17,300 hectares of faba beans were cultivated in Germany. In 2017 there were already 54,000 hectares grown. The increase is therefore $312 \%$.

The development of the acreage for the state of NRW shows this trend even more intense. There, the acreage of almost 1,600 hectares of faba beans in 2011 and 7,900 hectares in 2018 has increased almost fivefold. 


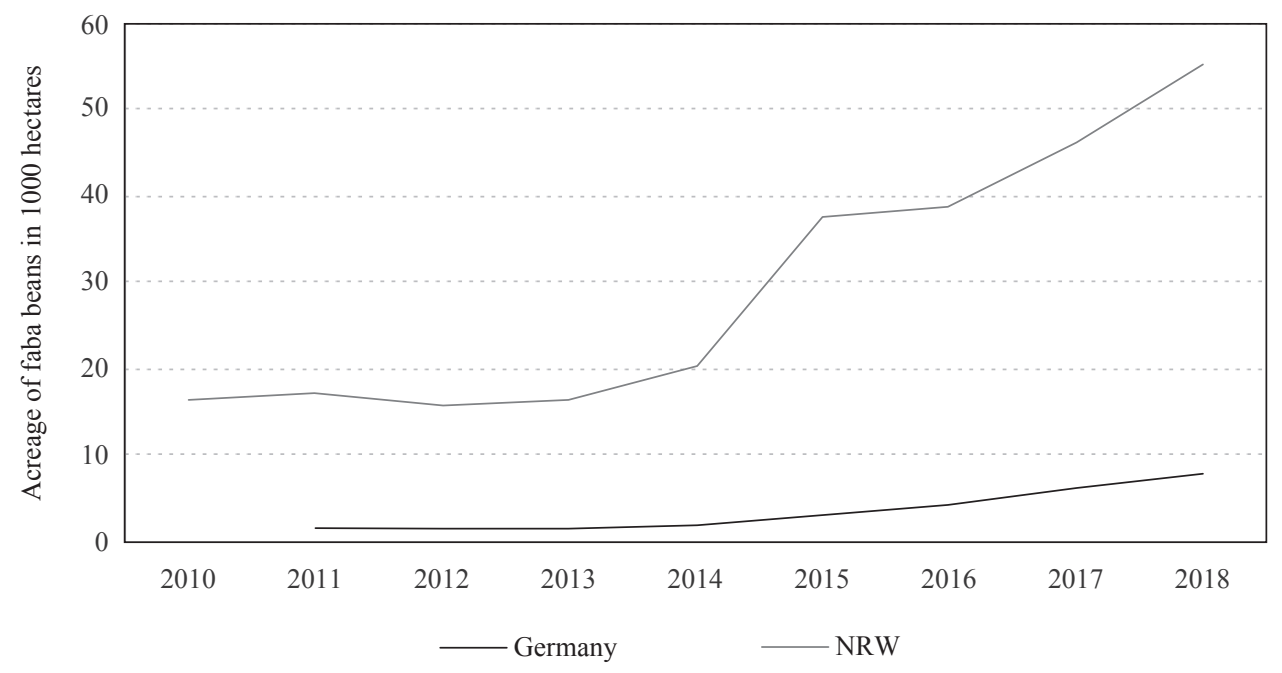

Figure 2. Development of the cultivated areas with faba beans in Germany and in the federal state of North Rhine-Westphalia in the years 2010 to 2017 (AMI, 2017; Destatis, 2018).

Figure 3 shows the cultivated areas by regions in NRW in which the association 'Rheinische Ackerbohne e.V.' is mainly active: the district of Aachen, Düren and Euskirchen, as well as the Erftkreis, Neuss and the Rhein-Sieg district, Heinsberg, Viersen, Kleve and Wesel. The acreage is, according to the Chamber of Agriculture NRW, at 1,320 ha in this area.

Figure 4 shows the livestock density in NRW. Comparing the cultivated areas with faba beans and the livestock density of the respective region, it is noticeable that in regions with particularly high livestock density the cultivation area of faba beans is very low. A possible explanation for this circumstance is an excess of nitrogen fertilizers in those regions. The application of animal manure is highly regulated in these

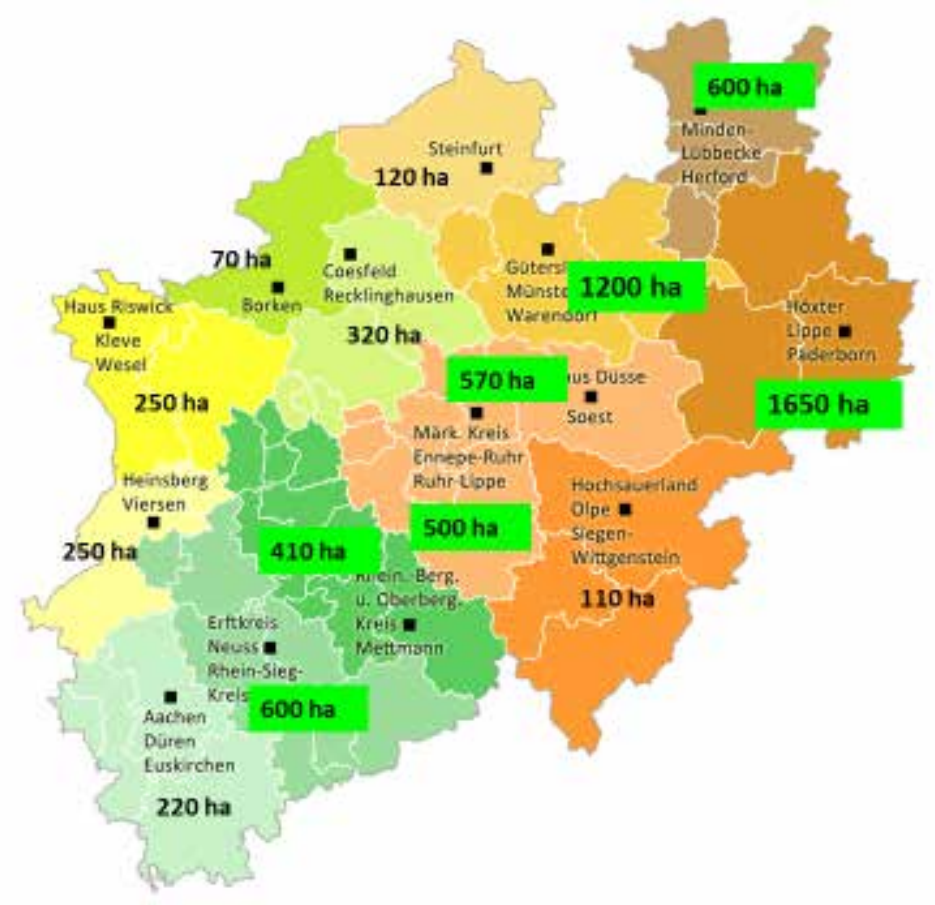

Figure 3. North Rhine-Westphalia. Cultivated area of faba beans in 2017 divided into regions (LWK-NRW, 2018). 


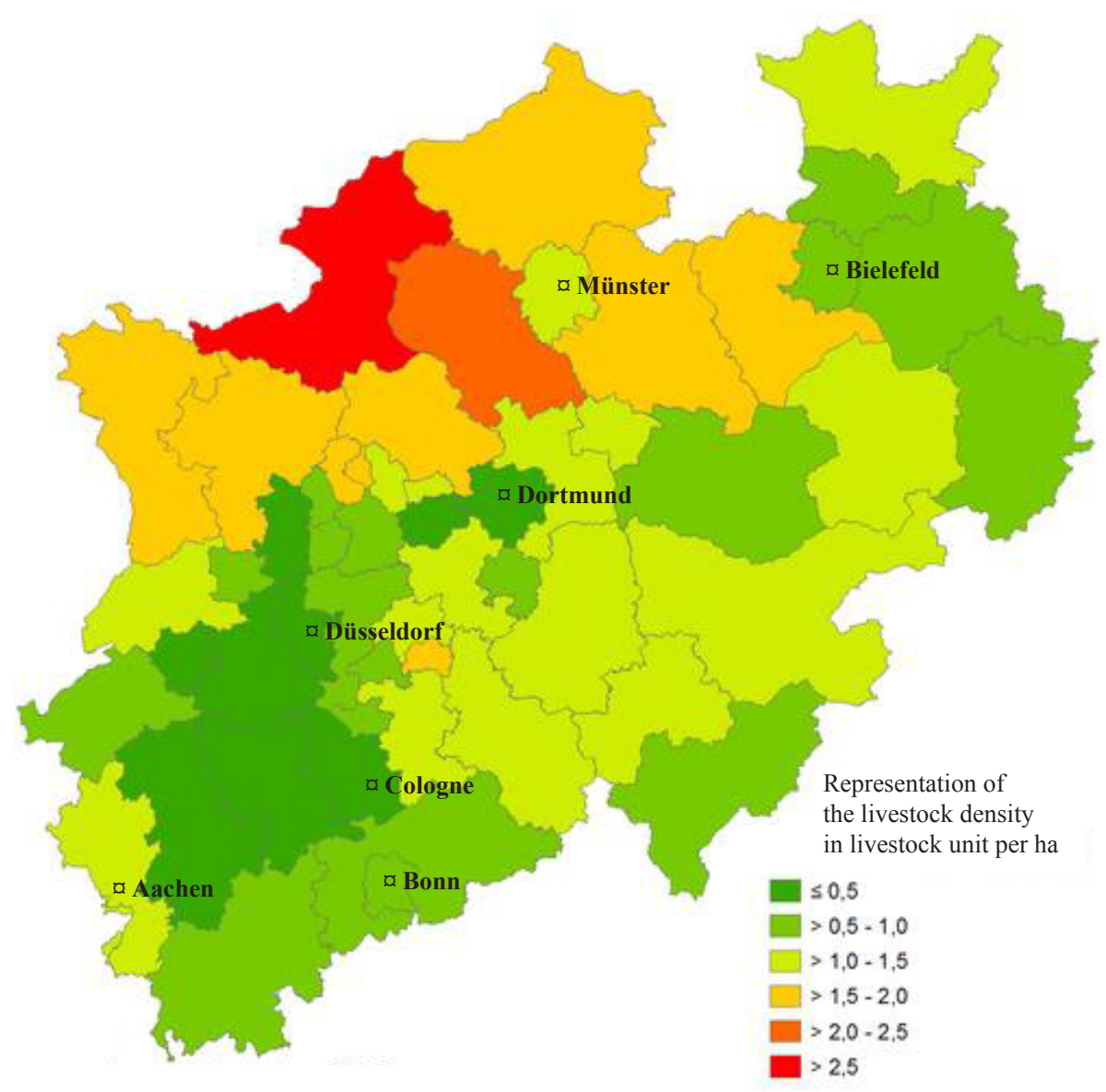

Figure 4. Representation of livestock density - in livestock unit per hectare (ha) of agricultural land - in different districts in NRW (Germany) (LANUV-NRW, 2020).

areas and increases the production costs for livestock farmers. Faba beans do not have to be fertilized and do not constitute urgently required nutrient sink in livestock intensive regions. Thus, livestock farming with nutrient surpluses constitutes a limiting factor for the faba bean cultivation.

\section{Description of the association and its objectives}

\subsection{Objectives of the association 'Rheinische Ackerbohne e.V.'}

The non-profit association 'Rheinische Ackerbohne e.V.' was founded at the beginning of the year 2017. The purpose of the association is to support the marketing of protein products made from faba beans from the Rhineland (the Western part of the federal state of NRW). The primary aim is to use the agricultural support program 'cultivation of diverse crops in agriculture' of the federal state NRW to increase the awareness of the benefits and the advantages of faba beans and to develop market structures for the domestically grown legume crop. The program 'cultivation of diverse crops in agriculture' explained in Section 1.6 allows farmers to cultivate faba beans economically for a total period of five years by funding the cultivation of grain legumes for this period while market prices are still considered to be to low. The members of the association use this time and attempt to open up a market for faba beans through sales and quantity bundling and to achieve an economically viable price for the protein products. The association 'Rheinische Ackerbohne e.V.' tries to open up new distribution channels and increase its share in the value chain. The five-year period of the political support program shall be used to develop market structures that will sustain a self-supporting cultivation of faba beans after the political support period will end. 
The association is not a producer organization in a strict sense and does not distribute faba beans directly. Each member operates his or her farm individually and benefits from the association that promotes the beans (Preuße, 2017). In total, the association bundles around 2,000 tons of faba beans per year (Bockholt, 2018: 16). Section 2.4. describes the difficulties of the agricultural trading companies in dealing with small amounts of a crop. Bundling quantities reduces transaction costs for trading companies and gives them incentives to offer higher prices.

It was and is an essential aim of the association's founding members to stimulate the consumers' demand for regional and GMO-free food and to offer consumers an alternative to imported soy (Aufmkolk, 2018: 16). Furthermore, the consumers' desire for sustainable production, awareness of the responsibility for nature, the environment and the habitat of bees is promoted.

\subsection{Regional classification of the association}

The association was founded in the Rhineland, in western Germany. A large part of the value-added chain is geographically located in the so-called 'Rhenih mining area'. This area is characterized by opencast lignite mining and power plants, but also by agriculture. The Rhenish mining area is one of the largest lignite mining areas in Europe, where lignite has been mined since about 1870 . The mined lignite is mainly used for energy generation. This method of power generation releases large quantities of the greenhouse gas $\mathrm{CO}_{2}$. Therefore, in order to achieve the German climate targets, there is a plan for renunciation of lignite-fired power plants. The decline of the local lignite industry is to be accompanied with structural policy. This should prevent social distortions in the course of a coal phase-out and help shape the economic future of the region. (Baur and Schwartzkopff, 2015).

The regional agricultural and food industry plays a central role in the phase-out of lignite-based electricity generation. The areas that are no longer used for open-cast mining will be extensively renatured and made available as agricultural or forestry land. Through the production of food, but also as a supplier of renewable raw materials, a modern agricultural policy in the region under the headline of 'bioeconomy' is planned to actively shape the upcoming process of change. As the area is at the same time one of the most advantageous regions in Europe for sustainable and productive agriculture and the home of a very strong food industry, and which is surrounded by markets that need food but also sustainable raw materials new possibilities for development emerge. With the 'bio-economy concept' a multi-stakeholder initiative aims to transform the region that has been strongly influenced by the use of fossil raw materials into a model region of the 'bioeconomy' (Staatskanzlei des Landes NRW, 2020).

\subsection{The association's members}

The association integrates various stakeholders related to faba beans. The association's member groups are farmers, consumers, food artisans, traders and nature conservationists (Bockholt, 2018: 16). Besides the farmers, local cooperatives, two private trading companies, supporters and rural associations are also members of the association (Preuße, 2018: 74). One year after the association's founding, it comprises 58 members, whereof 52 are farmers (Aufmkolk, 2018: 16).

\subsection{The association's services}

The service of the association is to raise the level of awareness concerning faba beans in different spheres of the public. To achieve this goal, the association's members implement a variety of activities. These include general communication activities, in particular to increase awareness, as well as specific activities related to the marketing of faba beans or the marketing of products containing faba beans. Another focus of the association is to get the positive environmental aspects provided by the cultivation of faba beans across to the consumer. 
Table 1. Composition of the board of the association 'Rheinische Ackerbohne e.V.' (Rheinische Ackerbohne, 2018).

\begin{tabular}{ll}
\hline Task in the association & Activity outside the association \\
\hline Managing director & Farmer - arable farming \\
Chairman & Farmer - arable farming \\
Executive board & Farmer - poultry farmer \\
Treasurer & Member of a cooperative society \\
Executive board & Farmer - livestock farmer \\
Executive board & Farmer - arable farming \\
Committee member & Regional cooperative \\
Committee member & Agricultural trading company \\
\hline
\end{tabular}

\section{- General activities of the association}

One of the general activities to promote the awareness of faba beans is that the association's board is frequently and numerously present at public events. They visit trade fairs, farm festivals and special conferences in order to draw attention to the association and to faba beans' benefits. Thereby board members get directly in contact with consumers and the public in general. With these measures, the association's members explain to consumers that those can promote and maintain environmental protection by buying regionally produced faba bean products.

Furthermore, the association operates its own website on which a detailed description of the faba bean's usability and the association's activities in social media networks are explained and linked (Bockholt, 2018: 16). Additionally, the website contains a frequently asked question (FAQ) list. Furthermore, the association is represented on social media sites, e.g. Facebook and Instagram, where it provides up-to-date information.

Furthermore, the association has developed field signs. They are placed on the edges of faba bean fields on which the association's members cultivate the protein plants. The signs contain information on the cultivation of faba beans, the versatile utilization possibilities as well as an enumeration of the advantages and benefits of the crop. Due to the high population density in the state of NRW and many people using the farming landscape for recreational purposes, these signs are meant to reach these target groups.

Moreover, the members of the association are the first contact persons for farmers, consumers and the interested public in general. They inform about the possibilities of the cultivation, the marketing and distribution as well as about the advantages and benefits of the consumption of faba beans.

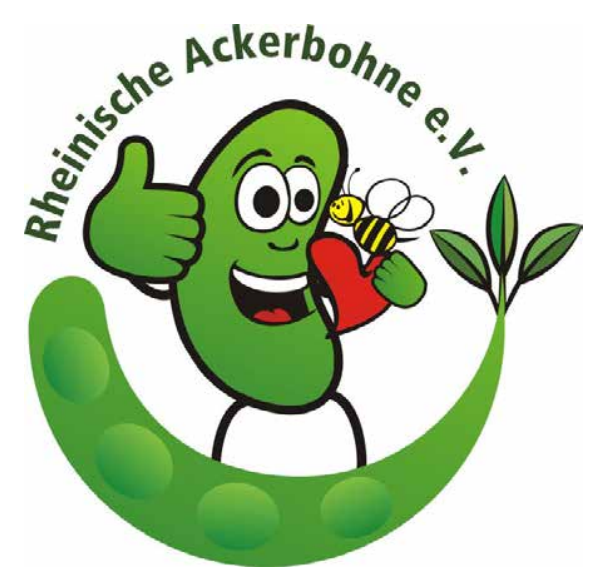

Figure 5. 'Acki' the logo of the association 'Rheinische Ackerbohne e.V.' (Rheinische Ackerbohne, 2018). 
Another mean for increasing the recognition value of faba beans, is the development of a logo by the association. This logo labels the various foods containing faba beans. Thus, consumers can recognize directly from the packaging the association's products. This logo is intended to create transparency. This unique and distinguishing feature on the products should create trust and security.

\section{- Specific activities of the association}

Specific activities to promote the marketing of faba beans or products with faba beans are as following:

So far, the association is known primarily for a specific faba bean bread. A broad and diverse bread baking tradition in Germany facilitates direct contact with consumers (Aufmkolk, 2018: 16). This has been initiated by the managing director of the association who got in contact with a regional baker and who asked him to create a bread from faba beans. After some trials, a mixture of $40 \%$ faba beans and $60 \%$ spelt turned out to be the most favorable one. It is characterized by its intense-floury taste, a firm crust, a low content of gluten and carbohydrates and a high protein content (Preuße, 2018). Meanwhile, five different bakery chains distribute the bread. In 2018 the following bakeries offered the faba bean bread (Rheinische Ackerbohne, 2018):

- Bakery Moss in Aachen, 1,500 pieces per week in 47 branches

- Bakery Kraus GmbH in Cologne, 43 branches

- Gilgen's bakery in different cities, 40 branches

- Kelzenberger bakery e.K. in Mönchengladbach, 1 branch

- Heinrich Tollkötter GmbH in Münster, 6 branches

- Bakery Dick GmbH in Heinsberg, 6 branches

- Bakery Evertzberg GmbH \& Co.KG in Remscheid, 50 branches

- Bakery Hinkel in Düsseldorf, 6 branches

In 2017, the faba bean bread of the Bakery Moss was awarded with the NRW State Award for Foodstuffs. Furthermore, a farm called 'Ruhrtal-Ei' (egg sales), whose owner is an association member, offers eggs from laying hens, which were fed with the domestic faba beans. The duress pork from the company 'Fleischwaren Esser' (meat products) is also labelled with the logo of the 'Rheinische Ackerbohne e.V.' Faba beans are used in pig feeding. At an international Fairtrade in Berlin, the butchery received the 'Regional Star' award for the Duress pork-concept in the innovation category (the pigs are fed with homegrown faba beans).

Another association member distributes GMO-free milk by faba beans in dairy cattle feeding. In addition, beekeepers put their bee colonies in the flowering fields of faba beans to produce faba bean honey. The sale of these products takes place almost exclusively through the direct marketing with the exception of the faba bean bread.

\subsection{Financing of the association}

The association keeps operational costs low and is financed by membership contributions. Sponsors of the association are a banking institution and an agricultural insurance company. No information is available on membership fees and the amount of financial support from the sponsoring institutions. Furthermore, the Federal Agency for Nutrition and Agriculture promotes the 'Rheinsche Ackerbohne e.V.'

\subsection{Stakeholders}

The stakeholders of the association 'Rheinische Ackerbohne e.V.' are primarily the association members. However, potential members and interested parties as well as consumers are to be included to the stakeholder basis in order to provide a comprehensive overview of the interests. 


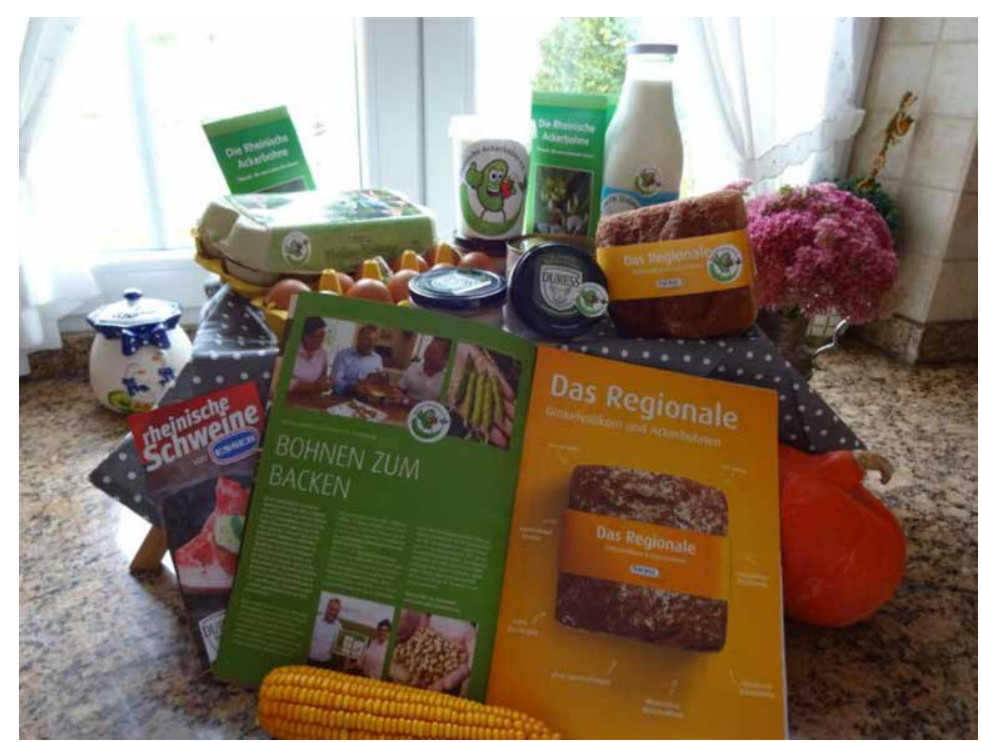

Figure 6. Products that are distributed with the logo of the association 'Rheinische Ackerbohne e.V'. (Rheinische Ackerbohne, 2018).

Members of the association (Preuße, 2018):

- Farmers who grow faba beans as part of the agri-environmental measure 'cultivation of diverse crops in agriculture' of the federal state of NRW.

- Farmers who use faba beans for the feeding of their own animals and market the products with the logo of the association.

- One local cooperative, as well as two private agricultural traders, managing the marketing of the faba beans.

- Supporters and associations.

- Supporters

Several private companies and organizations support the association (Bockholt, 2018: 16):

- Regional banks: Raiffeisenbank Erkelenz

- Insurance company: Vereinigte Hagel

- Other sponsoring associations (e.g. association GMO-free foodstuffs)

- Professional representation: chamber of agriculture NRW

\section{- Associations cooperating with the association 'Rheinische Ackerbohen e.V.'}

Besides the association 'Rheinische Ackerbohne e.V.', other institutions are directly or indirectly involved in the cultivation of faba beans. The interests of those associations are very different, however, overlap partially with those interests of the 'Rheinische Ackerbohen e.V.'. Therefore, there is cooperation between the institutions listed below and the association 'Rheinische Ackerbohne e.V.' This cooperation varies considerably from institution to institution. The various institutions are subsequently systematized and their specific activities are explained. There are private associations as well as state institutions.

\section{- Private associations}

The association 'Rheinische Ackerbohne e.V.' interacts with the above-mentioned associations and institutions and provides website-links to the cooperating institutions. The specific objectives of the different associations are more general and most times without specific reference to the faba beans, however, they are addressing environmental or nutritional problems in the solution on how faba beans can contribute. 
- Foundation 'Rheinische Kulturlandschaft'.

The purpose of the foundation 'Rheinische Kulturlandschaft' is the promotion of nature and landscape conservation in the Rhineland (NRW) by preserving and promoting the specialty, diversity and beauty of the rural cultural landscape, their sustainable use and their biotope plurality and biodiversity (Stiftung Rheinische Kulturlandschaft, 2020).

- Association 'Ernährung NRW e.V.'

NRW is(s)t gut, 'NRW is/eats well' is the slogan of the association 'Ernährung NRW e.V.' The objective of the association is to foster regional products from NRW to a higher degree of awareness and a better image (Ernährung NRW e.V., 2020).

- 'Zentralverband der Deutschen Geflügelwirtschaft e.V.' (Central Association of the German Poultry Industry e.V.) (ZDG).

The ZDG is a professional umbrella organization. This organization represents the interests of the German poultry industry at federal and EU level.

- 'Union zur Förderung von Öl- und Proteinpflanzen e.V.' (Union for the promotion of oil and protein plants e.V.) (UFOP).

UFOP unites all companies, associations and institutions involved in the production, processing and marketing of domestic oil and protein plants and brings together breeding, cultivation, the market and agricultural policy to form a concept based on the interests of the entire agricultural sector. The main objectives of UFOP are the representation of political interests in national and international committees, the optimization of agricultural production through the promotion of research, the support of variety testing, the development of new exploitation opportunities and PR work (UFOP, 2020).

\section{- Governmental institutions}

In addition to associations organized under private law, governmental institutions also support agricultural activities.

- 'Bundesministerium für Ernährung und Landwirtschaft' (Federal Agency for Nutrition and Agriculture) (BMEL).

One of the objectives of the BMEL is to ensure a balanced, healthy diet with safe food and to promote agriculture.

- 'Landesamt für Natur-, Umwelt- und Verbraucherschutz' (State Office for Nature Conservation, Environmental and Consumer Protection) (LANUV).

The LANUV is the technical-scientific authority of the state of NRW for nature, environmental and consumer protection. It is subordinated to the Ministry of Environment, Agriculture, Nature and Consumer Protection of this federal state. The LANUV advises the state government.

- 'Verbraucherschutzzentren NRW' (Consumer Protection Centers NRW) (Verbraucherzentrale, 2020). These centers provide advice and information on consumer protection issues. They help concerned consumers with legal questions and represent the interests of consumers.

- 'Demonstrationsnetzwerk erbse/bohne' (Demonstration network pea / bean)

The aim of the DemonetErBo is supporting the cultivation and processing of pea and bean legume varieties in Germany and to better match demand and supply (DemonetErBo, 2018).

\section{Discussion}

The model of the association 'Rheinische Ackerbohne e.V.' shows a possible approach for farmers to establish a regional value chain. It is an example that might be transferable to other regions as well.

\subsection{Advantages of regional value chains for the region}

The development of regional value chains has many advantages for the region. Regional production, processing and marketing will strengthen the competitive position of rural areas and retain purchasing power in the region. The result is a regional economic cycle that secures the employment situation in the region 


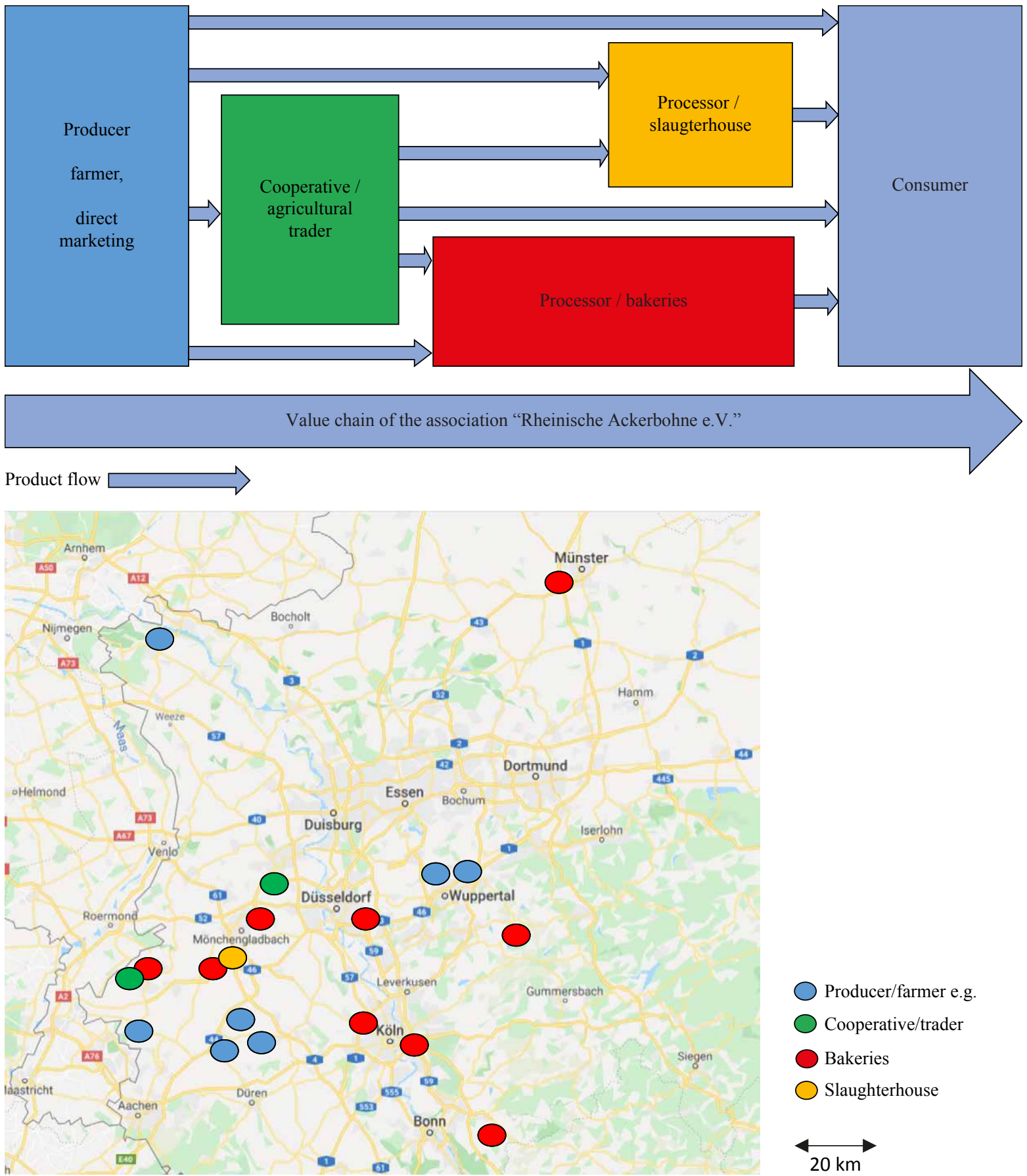

Figure 7. Regional value chain of the association 'Rheinische Ackerbohne e.V.'

and creates income opportunities. Furthermore, transport costs can be saved by the short distances, which in turn is more climate-friendly (Schubert u. Bühler, 2008: 7).

\subsection{Advantages of regional value chains for consumers}

Many consumers in Europe are sensitive to local foods. Many of them state altruistic reasons for the choice of these foods, such as the support of the local community or agriculture, the desire for sustainable food production or concerns about industrial food production (Håkansson, 2015). 
The Federal Government's Nutrition Report of 2016 describes that $76 \%$ of the population attach importance to regional food (BMEL, 2016:19).

By selecting regional products based on faba beans, consumers can choose a sustainably produced, genetically unmodified product. For regional products, there is transparency in food production and traceability. Knowing the origin and production of food helps to create the consumers' confidence. Another sales argument for consumers is the long cultivation tradition of faba beans in Germany (Hahne, 2006). Faba bean bread contains more protein and less carbohydrate, which consumers can use to improve their eating habits.

\subsection{Advantages of regional value chains for producers and processors}

The integration of services in the rural region brings advantages for the producers of faba beans. The association members of the association 'Rheinische Ackerbohnen e.V.' consider themselves as colleagues and not competitors. An exchange of information takes place quick and simple as for example mutual help in peak workloads. It could also be possible to save storage costs and to ensure a continuous supply of faba beans (Schubert u. Bühler, 2008: 7).

Producers also have the opportunity to advertise their products. On producers' farms, there is transparency from sowing to processing. Advertising with one's own person creates authenticity and ensures trust. For example, this could be highlighted by an invitation to visit the farm.

If the members of the value chain know each other, the agreement of common quality enhancement can be facilitated. If the producers and processors cooperate closely, it is also easier to work on product innovations and process improvements (Hahne, 2006).

Processors, particularly bakeries have the advantage that they can coordinate the purchase of faba beans centrally from an associated trading company and do not have to receive them from different farmers. This reduces transaction costs.

\subsection{Risks}

The question raises whether enough farmers are willing to join the association permanently and to increase the supply of faba beans in order to become attractive for potential large-scale customers. The aim of the association 'Rheinische Ackerbohne e.V.' of establishing stable market structures for faba beans in the Rhineland has not been achieved yet. Therefore, members of the association should consistently work on the continuity of the faba bean cultivation and marketing. An expansion of the association's activities might be needed to develop further markets for faba beans.

\subsection{Perspectives}

Expanding the value chain may enable an increase in sales. For this purpose, the distribution network should be expanded and the products marked with the logo of the 'Rheinische Ackerbohne e.V.'. Instead of being offered only in direct marketing, they also should be provided in the food retail industry.

Growing demand for non-GMO-feed could facilitate the use of faba beans in animal feeding. Combined with requirements for regional feed sources, faba beans of the 'Rheinischer Ackerbohne e.V.' could benefit from this trend.

To increase quantities and ensure stable supply, contract arrangements with farmers might be helpful and should be tested. 
In order to achieve a stronger interdependence of regional services, it is possible to involve regional restaurants as partners. These restaurants could develop and offer dishes containing faba beans produced by association members.

The food processing industry requires a more diverse supply of protein sources to be distinguished from animal proteins. Standardized protein meals from faba beans would be required to ensure a stable demand from food industry.

\subsection{Comparable examples from other regions in Germany}

In 2001, the Alb-Leisa Organic Producers' Association was founded in southern Germany. Lentils are cultivated and marketed in a supply association. The entire production is certified organic. The lentils are cleaned, processed and packed at the headquarters. From there, the lentils are sent to restaurants, food retailers or sold online directly to the end consumer. In 2009, the organic producer association consisted of 34 farmers, in 2017, 90 farmers were already producing lentils for the supplier association on an area of 350 ha. The company is now called Lauteracher-Alb-Feldfrüchte. 11 employees are engaged for the preparation of the goods, marketing and dispatch. The annual revenue of the producer association amounts to $€ 1.3$ million. This example shows a successfully grown value chain with the legume lentil.

\section{Conclusions}

The cultivation of faba beans offers a wide range of advantages and benefits. Within farm boundaries, the legumes improve crop rotations. Legumes also provide eco-system services that go beyond farm boundaries. Furthermore, the import dependency of protein feed can be reduced by the cultivation of domestic faba beans. The political conditions in Europe currently support the cultivation of grain legumes. This promotion can be used to establish market structures for domestically cultivated faba beans.

The aim of the association 'Rheinische Ackerbohne e.V.' is to establish an active and operational market for locally produced faba beans. The association bundles quantities. A continuous supply to feed manufacturers could be achieved. In addition, the association advertises faba beans and products made from faba beans and simultaneously improving public recognition and perception of faba beans.

The main objective of establishing an active market for faba beans in the region has not been achieved yet. The association members who cultivate faba beans are required to develop new forms of cooperation to further develop their activities. Such cooperation might help to establish the legume cultivation permanently.

Finally, it could also be analyzed, whether the activities of the association are transferable to other regions.

\section{Supplementary material}

Supplementary material can be found online at: https://doi.org/10.22434/IFAMR2019.0179

\section{Teaching Note.}

\section{Acknowledgements}

This work was carried out as part of the LegValue project. The project is funded by the European Union in the Horizon 2020 program under number 727672. 


\section{References}

Abel, H., W. Sommer and J. Weiß. 2020. Inhaltsstoffe, Futterwert und Einsatz von Ackerbohnen in der Nutztierfütterung. UFOP Union zur Förderung von Oel- und Proteinpflanzen e.V. Available at: https://tinyurl.com/y9zwgeep

Agrarmarkt Informations-Gesellschaft (AMI). 2017. Markt Bilanz - Getreide, Ölsaaten, Futtermittel 2017. AMI, Bonn, Germany.

Aufmkolk, V. 2018. Pionierarbeit für heimische Ackerbohne. Raps - Special Körnerleguminosen 36: 16-17.

Baur, A.H. and J. Schwartzkopf. 2015. Das Rheinische Revier von Morgen, den Strukturwandel gestalten. E3G, Berlin, Germany. Available at: https://tinyurl.com/y7nnonry

Bockholt, K. 2018. Bohnen besser bündeln. Agrarheute Pflanze und Technik 3: 14-18.

Bundesanstalt für Landwirtschaft und Ernährung (BLE). 2017. ELER in Deutschland Übersicht über die Nationale Rahmenregelung und die Programme der Länder. BLE, Bonn, Germany. Available at: https://tinyurl.com/y782x6er

De Visser, C., R. Schreuder and F. Stoddard. 2014. The EU's dependence on soya bean import for the animal feed industry and potential for EU produced alternatives. Oilseeds and Fats, Crops and Lipids 21(4): D407.

DemonetErBo. 2018. Demonstrationsnetzwerk Erbse/Bohne. Available at: http://www.demoneterbo. agrarpraxisforschung.de/index.php?id=121

Ernährung NRW e.V. 2020. Eine starke Gemeinschaft. Ernährung NRW e.V., Viersen, Germany. Available at: https://tinyurl.com/yd6xzlx6

European Commission. 2010. Eurobarometer, biotechnology. EC, Brussels, Belgium. Available at: https:// tinyurl.com $/ \mathrm{y} 7 \mathrm{kqutxg}$

European Union (EU). 2019. Sustainable land use - greening. EU, Brussels, Belgium. Available at: https:// ec.europa.eu/agriculture/direct-support/greening en

Federal Ministry of Food and Agriculture (BMEL). 2016. Protein crop strategy. BMEL, Bonn, Germany. Available at: https://tinyurl.com/yc668s5v

Geil, P.B. and J.W. Anderson. 1994. Nutrition and health implications of dry beans: a review. Journal of the American College of Nutrition 13(6): 549-558.

Hahne, U. 2006. Wertschöpfungsketten neu entdecken. LEADER Forum 3: 34-35.

Håkansson, A. 2015. What makes local food attractive to consumers? In: A. Petrenko and B. MüllerHansen (eds.) Interdisciplinary perspectives on local and regional food in the South Baltic Region. Kristianstad University Press, Kristianstad, Sweden. Available at: https://www.diva-portal.org/smash/ get/diva2:859766/FULLTEXT01.pdf

Hassan Wassef, H. 2004. Food habits of the Egyptians: newly emerging trends. La Revue de Santé de la Méditerranée orientale 10(6): 898-915.

Kezeya-Sepngang, B., I. Stute, W. Stauss, B.C. Schäfer and M. Mergenthaler. 2018. Möglichkeiten zur Bildung von verwertungsorientierten Preisindikatoren für Futtererbsen und Ackerbohnen im Vergleich zur veröffentlichten Marktpreisberichterstattung. Berichte über Landwirtschaft. https://doi.org/10.12767/ buel.v96i3.226

Köpke, U. und T. Nemecek. 2010. Ecological services of faba bean. Field Crops Research 115(3): 217-233. Landesamt für Natur, Umwelt und Verbraucherschutz Nordrhein-Westfalen (LANUV-NRW). 2020. LANUV stellt sich vor. Available at: https://www.lanuv.nrw.de/landesamt/lanuv-stellt-sich-vor/

Landwirtschaftskammer Nordrhein-Westfalen (LWK-NRW), 2018. Anbau vielfältiger Kulturen im Ackerbau. LWK-NRW, Münster, Germany. Available at: https://tinyurl.com/ydg9xeln

Lehmkuhl, K. 2018. Die rheinische Ackerbohne - eine fast vergessene heimische Feldfrucht. RaiffeisenBANKZEITung der Raiffeisenbank Erkelenz eG. Available at: https://tinyurl.com/y9ejmxww

Lucht, J. 2015. Public acceptance of plant biotechnology and GM crops. Viruses 7(8): 4254-4281.

Mitteldeutsche Produktenbörse (MPD). 2018. Aktuelle Notierungen. MPD, Dresden, Germany. Available at: http://www.mpb-online.com/aktuelles.php

Muehlbauer, F.J. and A. Tullu. 1997. Vicia faba L. New Crop Factsheet. Available at: https://www.hort. purdue.edu/newcrop/CropFactSheets/fababean.html 
Multari, S., D. Stewart and W.R. Russel. 2015. Potential of fava bean as future protein supply to partially replace meat intake in the human diet. Comprehensive Reviews in Food Science and Food Safety 14: 511-522.

Preuße, T. 2018. Heimat, die man schmeckt. in: DLG Mitteilungen 2.2018.

Profeta, A. and U. Hamm. 2019. Do consumers care about local feedstuffs in local food? Results from a German consumer study. NJAS-Wageningen Journal of Life Sciences 88: 21-30.

Rheinische Ackerbohne. 2018. Rheinische Ackerbohne e.V. Available at: https:/www.rheinische-ackerbohne.de Schubert D. and J. Bühler. 2008. A guideline for the management of regional value added partnerships. Regional Planning Authority Altmark, Salzwedel, Germany. Available at: https://tinyurl.com/y 7k9kdut

Spiegel, A.-K. 2014. Ökosystemleistungen von leguminosen. FiBL Deutschland, Frankfurt, Germany. Available at: https://tinyurl.com/ycy4zs8p

Staatskanzlei des Landes NRW. 2020. Strukturwandel im Rheinische Revier mit der Land-und Ernährungswirtschaft als Triebfeder. Staatskanzlei des Landes NRW, Düsseldorf, Germany. Available at: https://tinyurl.com/yadxlzbn

Statistische Bundesamt (Destatis). 2018. Land- und Forstwirtschaft, Fischerei-Bodennutzung der Betriebe (landwirtschaftlich genutzte Flächen). Available at: https://tinyurl.com/y9ve8h89

Stiftung Rheinische Kulturlandschaft. 2020. Naturschutz gemeinsam mit den Landwirten. Stiftung Rheinische Kulturlandschaft, Bonn, Germany. Available at: https://www.rheinische-kulturlandschaft.de/ueber-uns/

Union zur Förderung von Öl- und Proteinpflanzen (UFOP). 2020. Ideen säen. UFOP, Berlin, Germany. Available at: https://www.ufop.de/ufop-der-verband/aufgaben-und-ziele/

Verbraucherzentrale. 2020. Beratung bei den Verbraucherzentralen. Verbraucherzentrale, Düsseldorf, Germany. Available at: https://www.verbraucherzentrale.de/beratung

Wahbi, S., Y. Prin, J. Thioulouse, H. Sanguin, F. Baudoin, T. Maghraoui and R. Duponnois. 2016. Impact of wheat/faba bean mixed cropping or rotation systems on soil microbial functionalities. Frontiers in Plant Science 7: 1364.

Zander, P., T.S. Amjath-Babu, S. Preissel, M. Reckling, A. Bues, N. Schläfke and D. Murphy-Bokern. 2016. Grain legume decline and potential recovery in European agriculture: a review. Agronomy for Sustainable Development 36(2): 26.

Zentralverband der Deutschen Geflugelwirtschaft e.V. (ZDG). 2020. Wer sind wir. Available at: https:// zdg-online.de/\# 
